\title{
Optimizing Antibiotic Treatment Strategies for Neonates and Children: Does Implementing Extended or Prolonged Infusion Provide any Advantage?
}

\author{
Paola Costenaro ${ }^{1, *(\mathbb{D})}$, Chiara Minotti ${ }^{2}$, Elena Cuppini ${ }^{2}$, Elisa Barbieri ${ }^{1}$ (D), Carlo Giaquinto C.2,3 $^{1,2}$ \\ and Daniele Donà 1 \\ 1 Division of Paediatric Infectious Diseases, Department for Women's and Children's Health, \\ University of Padova, 35128 Padova, Italy; elisa.barbieri.5@phd.unipd.it (E.B.); \\ carlo.giaquinto@unipd.it (C.G.); daniele.dona@phd.unipd.it (D.D.) \\ 2 Department for Women's and Children's Health, University of Padova, 35128 Padova, Italy; \\ minotti.chiara@gmail.com (C.M.); elenacuppini28@gmail.com (E.C.) \\ 3 Paediatric Network for Treatment of AIDS (Penta) Foundation, 35128 Padua, Italy \\ * Correspondence: paola.costenaro@phd.unipd.it; Tel.: +39-347-9908-143
}

Received: 13 May 2020; Accepted: 12 June 2020; Published: 17 June 2020

\begin{abstract}
Optimizing the use of antibiotics has become mandatory, particularly for the pediatric population where limited options are currently available. Selecting the dosing strategy may improve overall outcomes and limit the further development of antimicrobial resistance. Time-dependent antibiotics optimize their free concentration above the minimal inhibitory concentration (MIC) when administered by continuous infusion, however evidences from literature are still insufficient to recommend its widespread adoption. The aim of this review is to assess the state-of-the-art of intermittent versus prolonged intravenous administration of antibiotics in children and neonates with bacterial infections. We identified and reviewed relevant literature by searching PubMed, from 1 January 12000 to 15 April 2020. We included studies comparing intermittent versus prolonged/continuous antibiotic infusion, among the pediatric population. Nine relevant articles were selected, including RCTs, prospective and retrospective studies focusing on different infusion strategies of vancomycin, piperacillin/tazobactam, ceftazidime, cefepime and meropenem in the pediatric population. Prolonged and continuous infusions of antibiotics showed a greater probability of target attainment as compared to intermittent infusion regimens, with generally good clinical outcomes and safety profiles, however its impact in terms on efficacy, feasibility and toxicity is still open, with few studies led on children and adult data not being fully extendable.
\end{abstract}

Keywords: antibiotic; time-dependent; continuous infusion; children; pediatric

\section{Introduction}

Infections acquired during hospitalization (HAIs) are particularly challenging among vulnerable populations, particularly neonates and children affected by chronic conditions such as immune deficiency or when admitted to the intensive care unit. The emergency of multidrug resistant bacteria as a common cause of HAIs, with very limited treatment options available for pediatric use, increases the need of optimizing the use of currently employed antibiotics, focusing on the best dosing strategy to improve overall outcomes as well as to limit the further development of antimicrobial resistance.

Prolonged and continuous infusion of time-dependent antibiotics aimed at increasing the probability of attaining pharmacokinetic/pharmacodynamic (PK/PD) targets may be considered to 
address challenges related to difficult-to-treat pathogens and improve efficacy [1]. Although conflicting results from studies conducted on adults cannot allow the recommendation of a widespread adoption of continuous infusion antibiotics in place of intermittent infusions [2-4], recent evidence suggest that administering beta-lactam antibiotics by prolonged or continuous infusions may reduce mortality, particularly in the case of difficult-to-treat pathogens such as Pseudomonas aeruginosa and/or bacteria with high minimal inhibitory concentration (MIC) [5-8].

Several aspects have to be taken into account in selecting the most appropriate antimicrobial treatment for patients with suspected or confirmed infection. Several aspects have to be considered in the decisional approach, including pathogens' characteristics and their sensitivity/resistance pattern to common antibiotics, the drugs' intrinsic pharmacodynamic features, the infection site and the patient's pathophysiology [9]. Composing the antimicrobial treatment puzzle is even more complex in neonates and children, due either to their age-related changes in physiological characteristics and to the limited antibiotic options that have already been approved for the pediatric population. Indeed, age-related differences in physiological characteristics have to be taken into account as they have an impact on the pharmacokinetic parameters of the administered drug, particularly due to variations in absorption, distribution, metabolism and excretion [10]. Moreover, further variations in pharmacokinetics of mainly hydrophilic antimicrobials occur in critically ill neonates and children [11,12].

Among all antibiotics, it has been shown that the bactericidal activity of time-dependent antibiotics, such as beta-lactams and oxazolidinones, is related to the duration of the maintenance of their free concentration above the minimal inhibitory concentration (MIC) during each dosing interval [13] while the killing activity of vancomycin is related to the area under the curve (AUC) and MIC ratio (AUC/MIC) [14]. Standard efficacy of beta-lactams is ensured when the duration of time the concentration exceeds the MIC ( $t>$ MIC) is at least $50 \%$ of the dosage interval, whereas a $t>$ MIC of $100 \%$ of the dosage interval should be ensured to reach optimal exposure, particularly in immune-compromised patients [12,15-17]. Indeed, a further improvement in efficacy of time-dependent antimicrobials has been observed for plasma concentrations four to five folds greater than the MIC $[12,18]$. In the case of vancomycin, it has been shown that standard efficacy is ensured reaching an AUC/MIC ratio higher than 400 [14]. Based on these pharmacodynamic determinants, prolonged or continuous infusion of time-dependent antimicrobials may represent the best form of administration to manage severe infections/sepsis by ensuring the highest steady-state concentrations.

In 2012, Walker and colleagues examined intermittent versus continuous administration of such antibiotics in children [19], reporting a lack of evidence in this particular population. So far, despite an observed increasing emergency of multidrug resistant bacteria even among the pediatric population, few antimicrobials have been in the pipeline for pediatric use, confirming the need of review the most appropriate use of commonly used drugs aimed at preserving as much as possible their efficacy and improve patients' outcome.

The aim of this narrative review is to evaluate the state-of-the-art in the literature on the intravenous use of systemic antibiotic treatment for both children and neonates with infections due to either Gram-positive and Gram-negative bacteria, particularly focusing on intermittent versus prolonged infusion.

\section{Methods}

\subsection{Search Strategy}

We identified and reviewed relevant literature by searching PubMed, from 1 January 2000 to 15 April 2020. Within the research strategy used for PubMed, combinations of the following search terms were used: "antibiotic", "antimicrobials", "children", "paediatric", "pediatric", "neonate", "infusion", "extended infusion," "prolonged infusion," "continuous infusion," "continuous administration," "dosing regimen," "dosing regimens," "continuous vs. intermittent," "extended vs. intermittent," "standard vs. prolonged," "extended vs. standard," or "intermittent vs. prolonged," 
"piperacillin/tazobactam", "meropenem", ceftazidime", "cefepime", "vancomycin", with a filter of "text availability: abstract, free full text and full text". Moreover, a reference list from eligible articles was reviewed to identify other potentially relevant studies. The last search was conducted on 15 April 2020.

\subsection{Selection Criteria}

In the current review, we included studies comparing the outcomes of different infusion regimens in the pediatric population, focusing on intermittent versus prolonged/continuous infusion rates. Randomized controlled trials, pharmacokinetic/pharmacodynamic studies, observational studies, and case series were included if involving pediatric patients (age 0-18 years) and if comparing prolonged or extended versus intermittent infusion of time-dependent antibiotics.

Manuscript comments, letters, editorials, conference abstracts and opinion articles were excluded.

\subsection{Data Collection}

Data were extracted using a standardized data collection form, which summarized information about authors, year of publication, study design, country, study period, setting, multicentric involvement, type of intervention, and main results.

\section{Results and Discussion}

Of 38,906 titles and abstracts, 114 were eligible for inclusion in this review, and ten studies were included, nine published in English and one in Spanish.

\subsection{Glycopeptides}

This class of antibiotics exhibits time-dependent bactericidal activity against most gram-positive bacteria, including methicillin-resistant Staphylococcus aureus (MRSA) and Enterococcus species; oral administration of glycopeptides is also recommended for the management of Clostridium difficile infection [20].

\subsection{Vancomycin}

Vancomycin inhibits cell wall synthesis by binding to the D-Ala-D-Ala terminal of the growing peptide chain during Gram positive cell wall synthesis. Details about spectrum of activity, adverse effects and hints to antibiotic resistance can be found in Table 2. Its volume of distribution is 0.4-1 L/kg [14] and protein binding is thought to be approximately 50\%, with estimated variability [21]. Vancomycin is usually administered intravenously, over at least $1 \mathrm{~h}$. In children aged from 1 month to 12 years with normal renal function the advised intravenous daily dose is $40-60 \mathrm{mg} / \mathrm{kg}$, administered in four divided doses [22] while in neonates up to 1 month, the recommended initial dose is $15 \mathrm{mg} / \mathrm{kg}$ followed by a maintenance dose of $10 \mathrm{mg} / \mathrm{kg}$ every $12 \mathrm{~h}$ in the first week of life and then once every $8 \mathrm{~h}$ until the age of one month. A wide inter-individual variability has been shown in preterm and term neonates [23].

Serum levels of vancomycin should be monitored and a target trough concentration goal of $15-20 \mu \mathrm{g} / \mathrm{mL}$ is recommended for serious, complicated infections, including methicillin-resistant staphylococcal-related infections [24,25].

\subsection{Pharmacokinetic/Pharmacodynamic Data}

The most useful target parameters to evaluate vancomycin PK/PD correlation are the area under the curve (AUC) and MIC. According to Rybak et al., an AUC/MIC ratio higher than 400 is related to a plasma trough level above $15 \mu \mathrm{g} / \mathrm{mL}$, assuming $1 \mathrm{mg} / \mathrm{L} \mathrm{MIC} \mathrm{or} \mathrm{less} \mathrm{[14].}$

In the pediatric population, PK/PD data on vancomycin are limited. A model study reports that the current empiric recommended vancomycin dose in children of $40 \mathrm{mg} / \mathrm{kg} / \mathrm{day}$ is unlikely to achieve 
the recommended pharmacodynamic target of AUC 24/MIC > 400 in case of methicillin-resistant S. aureus (MRSA) with MIC of $1.0 \mu \mathrm{g} / \mathrm{mL}$ or greater, suggesting that dose should be increased to $60 / \mathrm{mg} / \mathrm{kg} / \mathrm{die}$ [24]. Another prospective study reports that to achieve more rapidly the PK/PD targets in burn children with normal renal function, an initial dose of approximately $90-100 \mathrm{mg} / \mathrm{kg} / \mathrm{day}$ should be recommended [26]. Similar findings were reported by other studies based on PK data from children admitted to intensive care units (PICU) and Monte Carlo simulations, suggesting that on the basis of age, serum creatinine, and MIC distribution, a higher dose of vancomycin (60 to $70 \mathrm{mg} / \mathrm{kg} / \mathrm{day}$ ) could be necessary to achieve AUC/MIC $\geq 400$ [27-29]. In conclusion, most studies agree on the fact that PK models and Bayesian approaches may help in improving individualized target attainment [30].

\subsection{Clinical Outcome}

Although evidence from adults showed that continuous infusion of vancomycin (CIV) decreases the risk of nephrotoxicity and the incidence of infusion-related reactions while also decreasing time to therapeutic concentrations and drug cost at the same time, compared to IIV [31-33], limited evidence is currently available for the pediatric population.

Zylbersztajn et al. published a case series of six children between two months and seven years of age, being initially treated for MRSA sepsis with vancomycin 40 and $60 \mathrm{mg} / \mathrm{kg} / \mathrm{day}$ every 8-6 h. Because of poor outcome, they were all shifted to continuous infusion at $50 \mathrm{mg} / \mathrm{kg} / \mathrm{day}$, for 9 to 18 days. They reached blood levels between 10 and $25 \mathrm{ug} / \mathrm{mL}$, with a favorable outcome and negativization of cultures, with no signs of nephrotoxicity [34].

A randomized trial conducted by Gwee et al. compared the treatment outcome of continuous infusion of vancomycin (20-50 mg/kg/day) with the intermittent administration of $15 \mathrm{mg} / \mathrm{kg} / \mathrm{dose}$ every 24,12, 8 or $6 \mathrm{~h}$ according to gestational age in 111 infants admitted in NICU and PICU with suspected sepsis. Both administration regimens were related to clinical improvement and no significant side-effects were reported. However, only $41 \%$ (21 out of 51 ) of children of the intermittent intravenous (IIV) group achieved a target concentration of 15 to $25 \mathrm{mg} / \mathrm{L}$ at first steady-state level, compared to the $85 \%(45 / 53)$ of continuous intravenous (CIV) group [35].

The same outcome was evaluated in a retrospective study of 77 preterm infants (gestational age $<$ 34 weeks) with suspected late-onset sepsis (of those, an MRSA infection was diagnosed in 19 patients), treated with $20 \mathrm{mg} / \mathrm{kg} /$ day of vancomycin: $48 \mathrm{~h}$ after treatment initiation, $52.8 \%$ of infants of CIV achieved therapeutic levels, compared to $34.1 \%$ of patients of the IIV group. Microbiological outcomes and clinical responses did not differ significantly between the two groups [36].

Hurst and colleagues retrospectively evaluated the achievement of serum vancomycin goal concentration at different age range and the associated safety and tolerability among a cohort of 240 pediatric patients who were shifted from IIV to CIV. In their cohort, the average final total daily dose of CIV required to attain a therapeutic serum vancomycin concentrations (SVCs) was $54 \%$ to $64 \%$ of the final IIV dosing, suggesting that CIV has the potential to result in goal SVCs with much lower dosing than IIV [37]. As for safety outcomes, 19 patients of CIV had a mild to moderate decrease in creatinine clearance while a 17-year-old patient with a goal of 15 to $20 \mu \mathrm{g} / \mathrm{mL}$ had renal injury and one more 10-year-old patient with SVC 10 to $15 \mu \mathrm{g} / \mathrm{mL}$ presented renal failure, both being on other nephrotoxic medications, with serum creatinine level being back to normal at discharge.

As for compliance outcomes and availability for outpatients, there are to date no available data in the pediatric population, but evidence from studies involving adults seem to confirm a good tolerance, efficacy and safety profile for CIV with elastomeric pumps in home settings [38,39].

\subsection{B-Lactams Antibiotics}

Beta lactams are a family of time-dependent pharmacodynamic antibiotics that include penicillins, cephalosporins, carbapenems and monobactams, acting as inhibitors of bacterial cell wall synthesis [40]. Several studies showed that the bactericidal activity of beta lactams is highly predicted by the time during which the non-protein bounding drug concentration exceeds the MIC (fT > MIC) of the organism, 
at the site of the infections [41]. Although the precise fT $>$ MIC varies for different drug-bacteria combinations, a near-maximal bactericidal effect has been reported when the free drug concentration exceeds the MIC for $60-70 \%, 50 \%$, and $40 \%$ of the dosing interval for the cephalosporins, penicillins, and carbapenems, respectively [42,43]. Furthermore, it has been demonstrated that the bactericidal activity is maximized if free drug concentration remains four times higher than the MIC of the bacteria, without any advantage in further increasing the dose [15]. Prolonging the time of drug administration through either extended or continuous infusion may lead to maintain a stable trough concentration, minimizing high peak concentrations and therefore achieving such pharmacodynamic target more successfully than intermittent bolus dosing. Although some findings from RCTs conducted among the adult population provided conflicting conclusions [3,4], recent evidence has been supporting the use of prolonged or continuous infusion to reduce mortality and improve clinical outcomes [5-8].

\subsection{Piperacillin/Tazobactam}

Piperacillin/tazobactam (TZP) is a broad spectrum beta-lactam/beta-lactamase inhibitor combination widely used in hospitalized children with either suspected or documented severe infections, due to its wide spectrum of activity against Gram-positive/Gram-negative aerobic and anaerobic pathogens [44-48], including Pseudomonas aeruginosa (details in Table 2). Few pharmacokinetic data are available for piperacillin alone or piperacillin-tazobactam in children less than the age of two years, thus limiting its use in this population.

\subsection{Pharmacokinetic/Pharmacodynamic Data}

This drug is routinely administered with a 30-min or 1-h infusion time, as recommended for any other beta-lactams. However, recent studies challenge currently used dosing regimens and way of administration. According to De Cock et al., a Monte Carlo simulation conducted in a population of critically ill children receiving $75-100 \mathrm{mg} / \mathrm{kg}$ piperacillin every $6-8 \mathrm{~h}$ as a short infusion lead to very low probability of target attainment (PTA), estimated between $5.9 \%$ and $34 \%$ for piperacillin, potentially leading to subtherapeutic treatment. On the other side, continuous or prolonged (every $4 \mathrm{~h}$ ) infusions met the PTA criterion for piperacillin [49], defined as obtaining a PTA value of $\geq 90 \%$, as previously established [50]. Similar findings were reported by other studies, based on $\mathrm{pK}$ data from children admitted to intensive care unit (PICU), suggesting that prolonged or continuous administration may be more convenient, particularly in case of infection due to Gram-negative bacteria with higher MICs [51,52]. The same conclusions were highlighted considering as referral population either neonates and infants admitted to neonatal intensive care unit (NICU) [53] or febrile children with cancer [54,55], particularly when maximizing the dose of TZP (e.g., $400 \mathrm{mg} / \mathrm{kg} /$ day) [56]. Lastly, according to Thibault et al., infants and children older than six months seem to need extended TZP administrations to achieve a favorable PD target. The proposed dosage against bacteria with MICs of up to $16 \mathrm{mg} / \mathrm{L}$, in patients from six months to six years of age, was $130 \mathrm{mg} / \mathrm{kg} /$ dose every $8 \mathrm{~h}$ infused over $4 \mathrm{~h}$ (total daily dose, $390 \mathrm{mg} / \mathrm{kg} /$ day; total infusion time, $12 \mathrm{~h}$ ) [57].

\subsection{Clinical Outcome}

To date, few pieces of evidence evaluate the clinical impact of prolonged or continuous administration of piperacillin/tazobactam in children. Only one non-blinded RCT, published in 2019 by Solórzano-Santos et al., evaluated the clinical efficacy of TZP administered through continuous rather than intermittent infusion in onco-hematological children with febrile neutropenia. Continuous infusion included a loading dose of $75 \mathrm{mg} / \mathrm{kg}$ over $30 \mathrm{~min}$, followed by a $24 \mathrm{~h}$ continuous infusion of $300 \mathrm{mg} / \mathrm{kg} /$ day. Among 176 episodes assessed, no statistically significant difference was found in fever resolution, clinical cure rate or mortality between the continuous Infusion group and the intermittent administration group, with respectively 16 and 13 cases of treatment failure; one patient in each group died [58]. 
A retrospective case series published in 2017 showed that 29 (74\%) out of 39 children of five years (IQR 2-9) median age affected by an Enterobacteriaceae (mostly E. coli and K. pneumoniae) invasive infection and treated with prolonged TZP infusion achieved clinical cure at 21 days after treatment initiation. Although $38.5 \%(n=15)$ of patients had a readmission after 30 days, no deaths were reported in this cohort. Indeed, adverse effects related to extended infusion TZP were not experienced [59].

\subsection{Ceftazidime}

Ceftazidime is a third-generation cephalosporin frequently used in pediatric patients, being active against several Gram-positive and Gram-negative germs, including P. aeruginosa, and having a more favorable safety profile, if compared to other cephalosporins. Details can be found in Table 2. This drug is commonly prescribed in neonates with body weight $>1 \mathrm{~kg}$ and with less than seven days of life at $50 \mathrm{mg} / \mathrm{kg} /$ dose every $12 \mathrm{~h}$ while increasing doses are suggested if post-natal age is 8 to 28 days [60], up to $150 \mathrm{mg} / \mathrm{kg} /$ day divided every $8 \mathrm{~h}$ in case of meningitis [61].

According to the Red Book, the treatment of mild to moderate infections in infants, children and adolescents requires 90 to $250 \mathrm{mg} / \mathrm{kg} /$ day divided every $8 \mathrm{~h}$ (maximum daily dose $3 \mathrm{~g} /$ day), while severe infections $200 \mathrm{mg} / \mathrm{kg} /$ day divided every $8 \mathrm{~h}$ (maximum daily dose: $6 \mathrm{~g} /$ day, with even higher doses (300 mg/kg/day) being recommended for cystic fibrosis patients) [60].

\subsection{Pharmacokinetic/Pharmacodynamic Data}

Ceftazidime has an almost complete renal excretion (80-90\%) and has a low protein binding profile $(10 \%)$ [62]. It is usually administered in children with intermittent intravenous infusions over 15 to $30 \mathrm{~min}$, however the use of prolonged or continuous administration has been taken into consideration among the pediatric population, in order to optimize the time of free plasma drug concentrations above the MIC, thus enhancing its time-dependent antibacterial activity. Findings reported by several pharmacokinetics/pharmacodynamics studies suggested that continuous infusion administration of ceftazidime could optimize the time above the MIC for the pathogen therefore allowing higher concentrations to be achieved in tissues [63]. More recently, Cojutti et al. led a population pharmacokinetic analysis of continuous-infusion ceftazidime hematopoietic stem cell transplantation (HST). Ceftazidime steady-state (Css) plasma concentrations were monitored and among 46 children with 70 ceftazidime Css values considered, at the EUCAST clinical breakpoint of $8 \mathrm{mg} / \mathrm{L}$ for P. aeruginosa, Monte Carlo simulations showed that continuous-infusion ceftazidime doses of 4-6 g/day attained optimal PTAs (>90\%) across most of 16 different clinical scenarios based on four classes of eGFR and body surface area [64]. Dalle et al. confirmed the feasibility and safety of the continuous infusion regimen, as reported in their study on the pharmacokinetics of ceftazidime based on 20 febrile neutropenic pediatric patients [65].

\subsection{Clinical Outcome}

Few studies evaluated the clinical impact of continuous rather than intermittent administration of ceftazidime in the pediatric population.

In their prospective study, Rappaz et al. compared the treatment outcome of continuous and intermittent infusion of ceftazidime, both administered in different times at the same cohort of 14 children affected by cystic fibrosis. In the intermittent administration regimen group, the mean drug trough level concentration in serum was highly variable and $32 \%$ of samples had values below the MIC of pathogen isolated in sputum (P. aeruginosa) while the continuous infusion regimen ensured higher serum ceftazidime levels with no values below the MIC [66]. Despite this, both regimens showed a clinical improvement in terms of several pulmonary, inflammatory and nutritional variables, assessed at first and last day of treatment [66]. In addition, no significant side-effects were reported.

Lastly, according to the randomized crossover study of Hubert et al. conducted among children affected by cystic fibrosis, ceftazidime administered in a continuous infusion was as efficient as short 
infusion regimens and quality-of-life scores were comparable for the two groups. There were no reported toxicity issues [67].

As for continuous infusion ceftazidime for the treatment of outpatients, Jones et al. demonstrated its safe and effective use with once-daily changes of infusion device, provided the concentration and temperature of the infusion solution is controlled, in order to limit its degradation and pyridine formation [68].

\subsection{Cefepime}

Cefepime is a semi-synthetic, broad spectrum fourth-generation cephalosporin active against aerobic Gram-positive and Gram-negative pathogens including $P$. aeruginosa (details in Table 2). The parenteral administration of $50 \mathrm{mg} / \mathrm{kg}$ every $8 \mathrm{~h}$ (maximum dose: $6 \mathrm{~g}$ per day) is currently recommended for children and adolescents, traditionally administered as an intravenous infusion over $30 \mathrm{~min}$. Neonates should receive $30 \mathrm{mg} / \mathrm{kg} /$ dose every $12 \mathrm{~h}$, increasing the dose up to $50 \mathrm{mg} / \mathrm{kg} / \mathrm{dose}$ every $12 \mathrm{~h}$ in case of meningitis or severe infections due to P. aeruginosa [69].

\subsection{Pharmacokinetic/Pharmacodynamic Data}

Previous studies confirmed that in children aged 2 months to 16 years cefepime has a shorter half-life (1.26-1.93 h), compared to adults. In addition, a larger volume of distribution of cefepime was observed in the pediatric population [70]. For these reasons, strategies aimed at optimizing fT $>$ MIC are extremely interesting. However, very few studies assessed the use of cefepime as prolonged infusion, in the pediatric population. Findings from Shoji et al. showed that only prolonged infusion (e.g., within $3 \mathrm{~h}$ ) of $50 \mathrm{mg} / \mathrm{kg}$ guaranteed high rates of target attainment, up to $57 \%$ and $100 \%$ with every 12 and every $8 \mathrm{~h}$ dosing, in children older than 30 days of age and for infection due to Enterobacteriaceae with elevated MIC (8 $\mathrm{mcg} / \mathrm{mL})$ [71].

\subsection{Clinical Outcomes}

To date, no studies evaluated the impact of administering cefepime as prolonged infusion, among the pediatric population. Descriptive evidence published by Nichols et al., suggests that implementing extended-infusion of cefepime as standard of care is feasible and not related to major complications, in children with a median age of six years admitted to several pediatric departments, excluding intensive care units [72]. However, comparison of outcomes with patients receiving conventional intermittent infusions were beyond the scope of their study.

No studies evaluated the tolerability and compliance of outpatients' continuous infusion of ceftazidime with once-daily changes of infusion device. Voumard and colleagues described adult outpatients' treatment with continuous infusion cefepime, demonstrating a good compliance profile with an effective and safe approach [38].

\subsection{Meropenem}

Meropenem is a broad-spectrum beta-lactam antibiotic of the carbapenem class active against several Gram-positive and Gram-negative aerobic and anaerobic microorganisms, including extended-spectrum betha-lactamase (ESBL) producing bacteria (details in Table 2). It has a favorable penetration profile of tissues and body fluids alike, and it is well tolerated in preterm infants, neonates and children [73-75]. The suggested intravenous dose for susceptible infections in infants, children and adolescents is $20 \mathrm{mg} / \mathrm{kg} /$ dose every $8 \mathrm{~h}$ (maximum dose $1000 \mathrm{mg} / \mathrm{dose}$ ) [76]. In the case of central nervous system infections and of combined antibiotic treatment against multidrug resistant bacteria, such as carbapenemase-producer gram-negative bacteria, as much as for children affected by cystic fibrosis with pulmonary exacerbations, the pediatric recommended dose is $40 \mathrm{mg} / \mathrm{kg} /$ dose every eight hours (maximum dose $2000 \mathrm{mg} / \mathrm{dose}$ ) [76,77].

The inappropriate use of meropenem has led to an increasing incidence of carbapenemase-producing Enterobacteriaceae (CPE), which have now become endemic worldwide, including in Europe and particularly 
in Italy and Greece [78]. To face with the rapid spread of CPE, several efforts including the implementation of antimicrobial stewardship programs have been strongly recommended, aimed at enhancing the selection of carbapenem-sparing regimens and, when choosing a carbapenem-based treatment, trying to optimize its use in terms of ensuring optimal serum concentrations, in order to avoid the upraise of resistant breeds [79].

\subsection{Pharmacokinetic/Pharmacodynamic Data}

Meropenem is usually administered through infusion over $30 \mathrm{~min}$, as some evidences indicated that this drug may undergo a degradation, few hours after reconstitution [80,81]. Nonetheless, its bactericidal activity is known to be time-dependent [82-84]. Evidences from paediatric studies using Monte Carlo simulation found that a four-hour infusion may be suitable for pathogens with increased MICs, such as P. aeruginosa [74,85]. According to the prospective, multicenter, open-label pharmacokinetics study conducted by Pettit et al., 30 children affected by cystic fibrosis and with concomitant $P$. aeruginosa infection received extended infusion (e.g., administered in $3 \mathrm{~h}$ ) of $40 \mathrm{mg} / \mathrm{kg}$ meropenem every $8 \mathrm{~h}$. At Monte Carlo simulation, meropenem administered with prolonged $(3 \mathrm{~h})$ infusion had a greater likelihood of obtaining $40 \% \mathrm{fT}>$ MIC against pathogens with meropenem MICs of $1-8 \mathrm{mg} / \mathrm{L}$, compared to intermittent (30 $\mathrm{min}$ ) infusion [86], with a good tolerance profile.

Similar findings were reported by Cies et al. [87] that examined nine critically ill children aged one to nine years receiving meropenem: at Monte Carlo simulation only the three- to four-hour prolonged infusion and $24 \mathrm{~h}$ continuous infusion regimens achieved the optimal PTA ( $40 \% \mathrm{fT}>\mathrm{MIC})$ against all susceptible Gram-negative bacteria, while increasing dosage regimens to $120-160 \mathrm{mg} / \mathrm{kg} /$ day administered as continuous infusion may be necessary to achieve a PTA of $80 \% \mathrm{fT}>$ MIC, in critically ill children [87].

In their recent population pK study, Rapp et al. simulated dosing regimens of meropenem in critically ill paediatric patients with differences in renal function. Their results showed that the best regimen was continuous infusion ( 60 and $120 \mathrm{mg} / \mathrm{kg} /$ day), which allowed attainment of the target of $50 \% \mathrm{fT}>$ MIC and $100 \% \mathrm{fT}>$ MIC in patients with normal and increased creatinine clearance, with infection by germs with high MIC values $(>4 \mathrm{mg} / \mathrm{L}$ ), with no risks of accumulation. However, this was not demonstrated in children with a decreased creatinine clearance and severe renal failure [88].

\subsection{Clinical Outcomes}

The impact of extended infusion of meropenem in terms of clinical outcomes, such as mortality or clinical improvement, among the pediatric population is still unknown, as very few studies were conducted on this field. Recent evidence seems to confirm a better clinical outcome for neonates with Gram-negative late-onset sepsis (GN-LOS) treated with prolonged infusion of meropenem, if compared to conventional intermittent dosing [89]. In fact, according to the single center, open-label RCT conducted by Shabaan et al., neonates receiving extended $(4 \mathrm{~h})$ infusion had a significantly higher rate of both clinical improvement and microbiologic eradication, with a significantly lower neonatal mortality and shorter duration of respiratory support, compared to conventional infusion. In addition, prolonged infusion was associated with significantly less cases of acute kidney failure (AKI) in this group [89]. Meropenem was administered at a dosing regimen of $20 \mathrm{mg} / \mathrm{kg} / \mathrm{dose}$ every $8 \mathrm{~h}, 40 \mathrm{mg} / \mathrm{kg} / \mathrm{dose}$ in meningitis or Pseudomonas aeruginosa infection. 
Pettit et al. also confirmed that meropenem administered as prolonged infusion was well tolerated, as only one patient stopped therapy due to an unspecified adverse event [86].

Lastly, Padari et al., in their study reported no cases of toxicity for meropenem given with continuous infusion to seriously ill premature neonates. As for mortality, there was $1 / 9$ patient reported in the standard-infusion group and 1/10 in the prolonged-infusion group, both deaths occurred more than seven days after completion of therapy, with no relation to meropenem administration [90].

All studies including patient data are summarized in Table 1. Spectrum of activity, types of infections addressed, possible adverse effects of the considered antibiotics and information about the development of antibiotic resistance are detailed in Table 2. 
Table 1. Characteristics of included studies, reporting data on pediatric patients on intermittent vs. continuous infusion—study design, setting, population, antibiotic dose, toxicity, outcomes.

\begin{tabular}{|c|c|c|c|c|c|c|c|c|c|}
\hline \multirow[b]{2}{*}{ Included Studies } & \multirow[b]{2}{*}{ Study Design } & \multirow[b]{2}{*}{ Setting } & \multirow[b]{2}{*}{ Antibiotic and Dose } & \multicolumn{3}{|c|}{ Population } & \multirow[b]{2}{*}{ Primary Outcome } & \multirow[b]{2}{*}{ Toxicity } & \multirow{2}{*}{$\begin{array}{c}\text { Other Secondary } \\
\text { Outcomes }\end{array}$} \\
\hline & & & & $\begin{array}{c}\text { Total } \\
\text { (Analyzed) }\end{array}$ & Standard & $\begin{array}{l}\text { Prolonged/ } \\
\text { Continuous }\end{array}$ & & & \\
\hline $\begin{array}{c}\text { Zylbersztajn, Arch } \\
\text { Argent Pediatr } 2013 \\
\text { [34] }\end{array}$ & Case series & Spain, PICU & $\begin{array}{c}\text { Vancomycin } \\
\text { IIV } 40 \text { and } 60 \\
\mathrm{mg} / \mathrm{kg} / \text { day every } 8-6 \mathrm{~h} \text {, } \\
\text { shifted to CIV at } \\
50 \mathrm{mg} / \mathrm{kg} / \text { day }\end{array}$ & $\begin{array}{c}6 \text { children } \\
2 \\
\text { months-7 years }\end{array}$ & 6 & 6 & $\begin{array}{c}\text { Clinical cure (all had a } \\
\text { favourable outcome, } \\
\text { with negativization of } \\
\text { cultures) }\end{array}$ & No nephrotoxicity & $\begin{array}{l}\text { All patients } \\
\text { achieved levels } \\
\text { between } 10 \text { and } \\
25 \mathrm{ug} / \mathrm{mL}\end{array}$ \\
\hline $\begin{array}{c}\text { Gwee, Pediatrics } \\
2019 \text { [35] }\end{array}$ & RCT & $\begin{array}{c}\text { Australia, } \\
\text { NICU and } \\
\text { PICU }\end{array}$ & $\begin{array}{c}\text { Vancomycin } \\
\text { IIV } 15 \mathrm{mg} / \mathrm{kg} / \text { dose every } \\
24,12,8 \text { or } 6 \mathrm{~h} \\
\text { or CIV } 15 \mathrm{mg} / \mathrm{kg} \\
\text { loading dose followed } \\
\text { by } 20-50 \mathrm{mg} / \mathrm{kg} / \text { day }\end{array}$ & 111 infants & 54 & 57 & $\begin{array}{l}21 \text { of } 51(41 \%) \text { infants of } \\
\text { IIV group achieved } \\
\text { target concentrations at } \\
\text { the first steady-state } \\
\text { level compared with } \\
45 / 53(85 \%) \text { of CIV } \\
\text { group. }\end{array}$ & $\begin{array}{l}\text { No clinically } \\
\text { relevant adverse } \\
\text { effects were } \\
\text { observed in either } \\
\text { regimen }\end{array}$ & $\begin{array}{l}\text { The mean times to } \\
\text { bacteremia } \\
\text { clearance were } \\
55.3 \mathrm{~h} \text { in IIV group } \\
\text { and } 46.1 \mathrm{~h} \text { in CIV } \\
\text { group }\end{array}$ \\
\hline $\begin{array}{c}\text { Demirel, } \\
\text { Journal of Neonatal } \\
\text { Perinatal Medicine } \\
2015[36]\end{array}$ & $\begin{array}{l}\text { Retrospective } \\
\text { observational }\end{array}$ & $\begin{array}{l}\text { Turkey, } \\
\text { NICU }\end{array}$ & $\begin{array}{c}\text { Vancomycin } \\
\text { IIV } 20 \mathrm{mg} / \mathrm{kg} / \mathrm{die} \\
\text { Or CIV } 10 \mathrm{mg} / \mathrm{kg} \\
\text { loading dose followed } \\
\text { by } 20 \mathrm{mg} / \mathrm{kg} / \text { day }\end{array}$ & $\begin{array}{l}77 \text { preterm } \\
\text { infants }\end{array}$ & 41 & 36 & $\begin{array}{l}\text { At } 48 \mathrm{~h}, 52.8 \% \text { of } \\
\text { infants of CIV group } \\
\text { achieved vancomycin } \\
\text { therapeutic levels, } \\
\text { compared to } 34.1 \% \text { of } \\
\text { patients in IIV group }\end{array}$ & No nephrotoxicity & $\begin{array}{c}\text { No significant } \\
\text { differences between } \\
\text { groups, in terms of } \\
\text { microbiological and } \\
\text { clinical outcomes }\end{array}$ \\
\hline \multirow{2}{*}{$\begin{array}{l}\text { Hurst et al., Journal } \\
\text { of the Pediatric } \\
\text { Infectious Diseases } \\
\text { Societ, } 2018 \text { [37] }\end{array}$} & \multirow{2}{*}{$\begin{array}{l}\text { Retrospective } \\
\text { study }\end{array}$} & \multirow[b]{2}{*}{ USA } & & 240 children & & & $\begin{array}{l}\text { Overall: TDD of CIV } \\
\text { required to attain } \\
\text { therapeutic SVCs } \\
\text { according to age. } \\
76 / 240 \text { had a goal SVC } \\
\text { of } 10 \text { to } 15 \mu \mathrm{g} / \mathrm{mL} \\
164 / 240 \mathrm{had} \text { a goal of } 15 \\
\text { to } 20 \mu \mathrm{g} / \mathrm{mL}\end{array}$ & $\begin{array}{c}\text { A total of } 19 \\
\text { patients had a } 25 \% \\
\text { to } 49 \% \text { decrease in } \\
\text { creatine clearance } \\
(\mathrm{CrCl})\end{array}$ & \\
\hline & & & $\begin{array}{c}\text { Vancomycin } \\
\text { Goal SVC of } \\
10-15 \mu g / \mathrm{mL}: \\
\text { final TDD on IIV } \\
79.5 \mathrm{mg} / \mathrm{kg} / \mathrm{day}, \mathrm{shifted} \\
\text { to CIV } 46.2 \mathrm{mg} / \mathrm{kg} / \text { day } \\
\text { Goal } S V C \text { of } \\
15-20 \mu g / \mathrm{mL}: \\
\text { final TDD on IIV } \\
77.9 \mathrm{mg} / \mathrm{kg} / \mathrm{day}, \text { shifted } \\
\text { to CIV } 47 \mathrm{mg} / \mathrm{kg} / \text { day }\end{array}$ & $\begin{array}{l}54 \text { children } \\
>31 \text { days to } \\
<2 \text { years }\end{array}$ & 54 & $\begin{array}{c}\text { Goal SVC of } \\
10-15 \mu g / m L: \\
17 \\
\text { Goal SVC of } \\
15-20 \mu g / m L: \\
37\end{array}$ & $\begin{array}{c}\text { Goal } S V C \text { of } \\
10-15 \mu g / m L: \\
82 \% \text { of patients } \\
\text { achieved a therapeutic } \\
\text { SVC } \\
\text { Goal } S V C \text { of } \\
15-20 \mu g / m L: \\
51 \% \text { of patients } \\
\text { achieved a therapeutic } \\
\text { SVC }\end{array}$ & & $\begin{array}{c}\text { Frequency of } \\
\text { attaining goal SVCs } \\
\text { on CIV } \\
\text { Time to attainment } \\
\text { of a therapeutic } \\
\text { SVC on } \\
\text { CIV } \\
\text { Safety of CIV }\end{array}$ \\
\hline
\end{tabular}


Table 1. Cont

\begin{tabular}{|c|c|c|c|c|c|c|c|c|c|}
\hline \multirow[b]{2}{*}{ Included Studies } & \multirow[b]{2}{*}{ Study Design } & \multirow[b]{2}{*}{ Setting } & \multirow[b]{2}{*}{ Antibiotic and Dose } & \multicolumn{3}{|c|}{ Population } & \multirow[b]{2}{*}{ Primary Outcome } & \multirow[b]{2}{*}{ Toxicity } & \multirow[b]{2}{*}{$\begin{array}{l}\text { Other Secondary } \\
\text { Outcomes }\end{array}$} \\
\hline & & & & $\begin{array}{c}\text { Total } \\
\text { (Analyzed) }\end{array}$ & Standard & $\begin{array}{l}\text { Prolonged/ } \\
\text { Continuous }\end{array}$ & & & \\
\hline & & & $\begin{array}{c}\text { Vancomycin } \\
\text { Goal SVC of } \\
10-15 \mu g / m L: \\
\text { final TDD on IIV } \\
79.1 \mathrm{mg} / \mathrm{kg} / \mathrm{day}, \text { shifted } \\
\text { to CIV } 44.5 \mathrm{mg} / \mathrm{kg} / \text { day } \\
\text { Goal } S V C \text { of } \\
15-20 \mu g / \mathrm{mL}: \\
\text { final TDD on IIV } \\
78.7 \mathrm{mg} / \mathrm{kg} / \mathrm{day}, \text { shifted } \\
\text { to CIV } 45.6 \mathrm{mg} / \mathrm{kg} / \text { day }\end{array}$ & $\begin{array}{l}94 \text { children } \\
2 \text { to }<8 \text { years }\end{array}$ & 94 & $\begin{array}{c}\text { Goal SVC of } \\
10-15 \mu \mathrm{gg} / \mathrm{mL}: \\
38 \\
\text { Goal SVC of } \\
15-20 \mu \mathrm{g} / \mathrm{mL}: \\
56\end{array}$ & $\begin{array}{c}\text { Goal SVC of } \\
10-15 \mu g / m L: 82 \% \text { of } \\
\text { patients achieved a } \\
\text { therapeutic SVC } \\
\text { Goal SVC of } \\
15-20 \mu g / m L: \\
41 \% \text { of patients } \\
\text { achieved a therapeutic } \\
\text { SVC }\end{array}$ & & \\
\hline & & & $\begin{array}{c}\text { Vancomycin } \\
\text { Goal SVC of } \\
10-15 \mu \mathrm{g} / \mathrm{mL}: \\
\text { final TDD on IIV } \\
72.5 \mathrm{mg} / \mathrm{kg} / \text { day, shifted } \\
\text { to CIV } \\
41.5 \mathrm{mg} / \mathrm{kg} / \mathrm{dayGoal} \\
\text { SVC of } 15-20 \mu g / \mathrm{mL}: \\
\text { final TDD on IIV } \\
72.9 \mathrm{mg} / \mathrm{kg} / \mathrm{day}, \text { shifted } \\
\text { to CIV } 43.1 \mathrm{mg} / \mathrm{kg} / \text { day }\end{array}$ & $\begin{array}{l}92 \text { children } \\
8 \text { to }<18 \text { years }\end{array}$ & 92 & $\begin{array}{c}\text { Goal SVC of } \\
\text { 10-15 } \mu \mathrm{g} / \mathrm{mL}: 21 \\
\text { Goal SVC of } \\
15-20 \mu \mathrm{g} / \mathrm{mL}: 71\end{array}$ & $\begin{array}{c}\text { Goal SVC of } \\
10-15 \mu g / m L: \\
67 \% \text { of patients } \\
\text { achieved a therapeutic } \\
\text { SVC } \\
\text { Goal SVC of } \\
15-20 \mu g / m L: \\
76 \% \text { of patients } \\
\text { achieved a therapeutic } \\
\text { SVC }\end{array}$ & $\begin{array}{l}\text { Goal SVC of } \\
10-15 \mu g / m L \text { : } \\
\text { renal failure in a } \\
10 \text {-year-old } \\
\text { Goal SVC of } \\
15-20 \mu g / m L \text { : } \\
\text { renal injury in a } \\
17 \text {-year-old }\end{array}$ & \\
\hline $\begin{array}{l}\text { Solórzano-Santos } \\
\text { et al., Rev Invest Clin } \\
2019 \text { [58] }\end{array}$ & $\begin{array}{l}\text { Non-blinded } \\
\text { RCT }\end{array}$ & $\begin{array}{c}\text { Mexico, } \\
\text { third-level } \\
\text { paediatric } \\
\text { hospital }\end{array}$ & $\begin{array}{c}\text { Piperacillin/tazobactam, } \\
300 \mathrm{mg} / \mathrm{kg} / \text { day IA }(4 \\
\text { doses) versus CI of } \\
300 \mathrm{mg} / \mathrm{kg} / \text { day over } \\
24 \mathrm{~h}(\text { after loading dose } \\
\text { of } 75 \mathrm{mg} / \mathrm{kg} \text { over } \\
30 \mathrm{~min})\end{array}$ & $\begin{array}{l}176 \text { episodes } \\
\text { of febrile } \\
\text { neutropenia in } \\
\text { children }\end{array}$ & 100(Group 1) & 76 (Group 2) & $\begin{array}{l}\text { Clinical cure (fever } \\
\text { decreased in the first } 48 \\
\text { after therapy start in } \\
45 \% \text { of patients; } \\
\text { improvement of signs } \\
\text { and symptoms at } 72 \mathrm{~h} \\
\text { in } 80 \% \text { and } 73 \% \text { of } \\
\text { patients in the two } \\
\text { groups respectively) } \\
\text { Treatment failure } \\
\text { (13/100 failures in } \\
\text { Group } 1 \text { and } 16 / 76 \text { in } \\
\text { Group 2) }\end{array}$ & l & $\begin{array}{c}\text { No differences in } \\
\text { fever resolution, } \\
\text { clinical cure rate or } \\
\text { mortality ( } 2 \\
\text { patients died, one } \\
\text { for each group). }\end{array}$ \\
\hline
\end{tabular}


Table 1. Cont.

\begin{tabular}{|c|c|c|c|c|c|c|c|c|c|}
\hline \multirow[b]{2}{*}{ Included Studies } & \multirow[b]{2}{*}{ Study Design } & \multirow[b]{2}{*}{ Setting } & \multirow[b]{2}{*}{ Antibiotic and Dose } & \multicolumn{3}{|c|}{ Population } & \multirow[b]{2}{*}{ Primary Outcome } & \multirow[b]{2}{*}{ Toxicity } & \multirow[b]{2}{*}{$\begin{array}{l}\text { Other Secondary } \\
\text { Outcomes }\end{array}$} \\
\hline & & & & $\begin{array}{c}\text { Total } \\
\text { (Analyzed) }\end{array}$ & Standard & $\begin{array}{l}\text { Prolonged/ } \\
\text { Continuous }\end{array}$ & & & \\
\hline $\begin{array}{l}\text { Knoderer et al., JPPT } \\
\text { Clin Inv } 2017 \text { [59] }\end{array}$ & $\begin{array}{l}\text { Retrospective } \\
\text { case series }\end{array}$ & $\begin{array}{l}\text { USA (general } \\
\text { surgery, } \\
\text { oncology) }\end{array}$ & $\begin{array}{l}\text { Piperacillin/tazobactam, } \\
112.5 \mathrm{mg} / \mathrm{kg} \\
\text { intravenously (IV) every } \\
8 \mathrm{~h} \text {, infused by EI (over } \\
4 \mathrm{~h} \text { ) }\end{array}$ & $\begin{array}{l}39 \text { children } \\
\text { with } \\
\text { Enterobacteriaceae } \\
\text { related } \\
\text { infection } \\
\text { (mostly E. coli } \\
\text { \& Klebsiella) }\end{array}$ & e & 39 & $\begin{array}{c}\text { Clinical cure } \\
(29 / 39(74 \%) \text { met } \\
\text { clinical cure, at } 21 \text { days } \\
\text { after TZP initiation) }\end{array}$ & / & $\begin{array}{c}\text { length of stay } \\
\text { duration of TZP } \\
\text { treatment30-day } \\
\text { readmission }(15 / 39 \\
(38.5 \%) \text { had a } 30 \\
\text { days readmission) } \\
\text { 30-day mortality } \\
\text { (No deaths) }\end{array}$ \\
\hline $\begin{array}{c}\text { Rappaz I, Eur J } \\
\text { Pediatr } 2000 \text { [66] }\end{array}$ & $\begin{array}{l}\text { Prospective } \\
\text { cross over } \\
\text { study }\end{array}$ & $\begin{array}{l}\text { Switzerland(Cystic } \\
\text { Fibrosis Centre) }\end{array}$ & $\begin{array}{c}\text { Ceftazidime } \\
\text { Thrice-a-day } 20 \mathrm{~min} \\
200 \mathrm{mg} / \mathrm{kg} / \text { day IA for } 14 \\
\text { days versus CI of } \\
\text { ceftazidime } 100 \\
\mathrm{mg} / \mathrm{kg} / \text { day for } 14 \text { days }\end{array}$ & $\begin{array}{c}14 \text { children } \\
\text { with cystic } \\
\text { fibrosis }(\mathrm{CF})\end{array}$ & 14 & 14 & $\begin{array}{l}\text { Clinical cure: efficacy } \\
\text { of both regimens } \\
\text { assessed by comparing } \\
\text { surrogate markers } \\
\text { (all patients improved } \\
\text { clinically, no differences } \\
\text { in terms of variation of } \\
\text { several pulmonary, } \\
\text { inflammatory and } \\
\text { nutritional variable) }\end{array}$ & $\begin{array}{l}\text { No clinically } \\
\text { relevant adverse } \\
\text { effects were } \\
\text { observed in both } \\
\text { regimen }\end{array}$ & $\begin{array}{l}\text { Tolerability and } \\
\text { feasibility of } C I \\
\text { regimen; Positive } \\
\text { impact on the } \\
\text { quality of life of } C F \\
\text { children }\end{array}$ \\
\hline $\begin{array}{c}\text { Hubert D, } \\
\text { Antimicrobial } \\
\text { Agentis and } \\
\text { Chemotherapy, } 2009 \\
\text { [67] }\end{array}$ & $\begin{array}{l}\text { multicenter, } \\
\text { randomized } \\
\text { crossover } \\
\text { study }\end{array}$ & $\begin{array}{c}\text { France, } 15 \text { (Cystic } \\
\text { Fibrosis Centers) }\end{array}$ & $\begin{array}{c}\text { Ceftazidime } \\
\text { IA (thrice-daily) of } \\
200 \mathrm{mg} / \mathrm{kg} / \text { day versus } \mathrm{CI}, \\
\text { after a loading dose of } 60 \\
\mathrm{mg} / \mathrm{kg}\end{array}$ & $\begin{array}{l}70 \text { children } \\
\text { with CF }\end{array}$ & $\begin{array}{l}\text { 34: } \\
\text { thrice-daily } \\
\text { ceftazidime } \\
\text { short } \\
\text { infusions for } \\
\text { the first } \\
\text { course and } \\
\text { ceftazidime CI } \\
\text { for the second } \\
\text { course (group } \\
\text { A) }\end{array}$ & $\begin{array}{l}\text { 36: ceftazidime CI } \\
\text { for the first course } \\
\text { and short } \\
\text { infusions for the } \\
\text { second course } \\
\text { (group B). }\end{array}$ & $\begin{array}{c}\text { Efficacy: } \\
\text { ITT: no difference in } \\
\text { FEV } 1 \text { (assessed at the } \\
\text { end of therapy) } \\
\text { between group A and } \\
\text { group B, with }+7.6 \% \\
\text { after continuous } \\
\text { infusion and }+5.5 \% \\
\text { after short infusions) } \\
(90 \% \text { CI 2.1 ( }-0.3 \text { to } 5.2) \text {, } \\
\text { p 0.15) but better } \\
\text { clinical outcome after } \\
\text { continuous ceftazidime } \\
\text { treatment in patients } \\
\text { harboring resistant } \\
\text { isolates }(p<0.05) .\end{array}$ & $\begin{array}{c}\text { Tolerance: } \\
124 \text { adverse events } \\
\text { reported ( } 68 \text { on SIs } \\
\text { and } 56 \text { on CI) in } 50 \\
\text { patients, of those } \\
\text { only } 2 \text { were } \\
\text { considered severe }(1 \\
\text { after the SIs } \\
1 \text { after the CI) }\end{array}$ & $\begin{array}{c}\text { Similar } \\
\text { quality-of-life } \\
\text { scores for both } \\
\text { treatments, } \\
\text { however } 82 \% \text { of the } \\
57 \text { patients } \\
\text { preferred the CI } \\
\text { administration, } \\
\text { rather than short } \\
\text { infusions }\end{array}$ \\
\hline
\end{tabular}


Table 1. Cont.

\begin{tabular}{|c|c|c|c|c|c|c|c|c|c|}
\hline \multirow[b]{2}{*}{ Included Studies } & \multirow[b]{2}{*}{ Study Design } & \multirow[b]{2}{*}{ Setting } & \multirow[b]{2}{*}{ Antibiotic and Dose } & \multicolumn{3}{|c|}{ Population } & \multirow[b]{2}{*}{ Primary Outcome } & \multirow[b]{2}{*}{ Toxicity } & \multirow{2}{*}{$\begin{array}{c}\text { Other Secondary } \\
\text { Outcomes }\end{array}$} \\
\hline & & & & $\begin{array}{c}\text { Total } \\
\text { (Analyzed) }\end{array}$ & Standard & $\begin{array}{l}\text { Prolonged/ } \\
\text { Continuous }\end{array}$ & & & \\
\hline $\begin{array}{l}\text { Shabaan AE, Pediatr } \\
\text { Infect Dis J } 2017 \text { [89] }\end{array}$ & $\begin{array}{l}\text { Single center, } \\
\text { open-label } \\
\text { RCT }\end{array}$ & $\begin{array}{l}\text { Egypt, } \\
\text { NICU }\end{array}$ & $\begin{array}{c}\text { Meropenem } \\
60 \mathrm{mg} / \mathrm{Kg} / \text { day } \\
(120 \mathrm{mg} / \mathrm{kg} / \text { day if } \\
\text { meningitis/P.aeruginosa), } \\
\text { IA (over } 30 \text { min) in } \\
\text { group1 versus EI (over } \\
4 \mathrm{~h} \text { ) in group2 }\end{array}$ & $\begin{array}{c}102 \text { neonates } \\
(<28 \text { days }) \\
\text { with } \\
\text { late-onset } \\
\text { sepsis due to } \\
\text { GNB }\end{array}$ & 51 & 51 & $\begin{array}{c}\text { Clinical success: } \\
\text { 31/51 (61\%) EI vs. 17/51 } \\
\text { (33\%) IA, } p=0.009 \\
\text { Odds Ratio: } 3.10(1.38, \\
6.96) \\
\text { Microbiologic success: } \\
\text { eradication at MER 7th } \\
\text { day }(82 \% \text { prolong vs. } \\
56.8 \% \text { conv, } p=0.009) \\
\text {-shorter duration of } \\
\text { respiratory support [4 } \\
\text { days in prolong }(0-18) \\
\text { versus } 12.5 \text { days in conv } \\
\text { (5.7-17.2) vs., } p=0.03]\end{array}$ & $\begin{array}{c}\text { Reduced risk of } \\
\text { AKI with EI (3/51, } \\
6 \% \text { ) compared to IA } \\
(12 / 51,3.5 \%) \\
p=0.02\end{array}$ & $\begin{array}{c}\text { Mortality: } 7 / 51 \\
(14 \%) \text { EI vs. } 16 / 51 \\
\text { (31\%) IA, } p=0.03) \\
\text { RR: } 0.44(0.20-0.47) \\
*\end{array}$ \\
\hline $\begin{array}{c}\text { Padari et al., AAC, } \\
2012[90]\end{array}$ & $\begin{array}{l}\text { Prospective, } \\
\text { open label } \\
\text { study }\end{array}$ & Estonia, NICU & $\begin{array}{c}\text { Meropenem } \\
20 \mathrm{mg} / \mathrm{kg} \text { bid over } \\
30 \mathrm{~min} \mathrm{vs.} 4 \mathrm{~h} \text { infusion }\end{array}$ & $\begin{array}{l}19 \text { neonates } \\
(<23 \mathrm{w}, \mathrm{BW} \\
<1.2 \mathrm{~kg})\end{array}$ & 9 & 10 & $\begin{array}{c}\text { Steady-state PK: } \\
\text { higher C max in the } \\
\text { short-infusion group } \\
\text { and a higher time to } \\
\text { drug C max in serum (T } \\
\text { max) in the } \\
\text { prolonged-infusion } \\
\text { group. All other PK } \\
\text { parameters were } \\
\text { similar. } \\
\text { - All of the patients in } \\
\text { the short-infusion } \\
\text { group and } 8 / 10 \text { in the } \\
\text { long-infusion group } \\
\text { achieved an fT MIC of } \\
\text { 100\% for an MIC of } \\
2 \text { mg/L. } \\
\text { Safety of meropenem } \\
\text { given via short or } \\
\text { prolonged infusion }\end{array}$ & None & $\begin{array}{c}\text { Mortality: } \\
\text { 1/9 in IA vs. } 1 / 10 \text { in } \\
\text { EI ( }>7 \text { days after } \\
\text { completion of } \\
\text { therapy) } \\
\text { In VLBW neonates, } \\
\text { meropenem } \\
\text { infusions of } 30 \text { min } \\
\text { are optimal }\end{array}$ \\
\hline
\end{tabular}

Abbreviations: CNS: Central Nervous System; PICU: Pediatric Intensive Care Unit; RCT: Randomized Controlled Trial; IIV: Intermittent Infusion Vancomycin; CIV: Continuous Infusion Vancomycin; SVC: Serum Vancomycin Concentration; NICU: Neonatal Intensive Care Unit; IA: Intermittent Administration; CI: Continuous Infusion; EI: Extended Infusion, TDD: Total Daily Dose; TZP: Piperacillin/Tazobactam; CF: Cystic Fibrosis. 
Table 2. Spectrum of activity and infection types, adverse effects and antimicrobial resistance for the considered antibiotics.

\begin{tabular}{|c|c|c|c|}
\hline Antibiotic & $\begin{array}{l}\text { Spectrum of Activity } \\
\text { Infection Types }\end{array}$ & Adverse Effects & Antimicrobial Resistance \\
\hline \multicolumn{4}{|l|}{ Glycopeptides } \\
\hline Vancomycin & $\begin{array}{l}\text { Bactericidal for several aerobic and anaerobic gram-positive } \\
\text { bacteria, including coagulase-negative Staphylococcus and S. } \\
\text { aureus. Bacteriostatic for enterococci. } \\
\text { Skin and soft tissue infections, bone and joint infections, } \\
\text { bloodstream infections and endocarditis, CNS infections, C. } \\
\text { difficile colitis (if administered orally) 10.14. }\end{array}$ & $\begin{array}{l}\text { Infusion-related adverse effects: } \\
\text { "red man syndrome"; pain in the area of injection; allergic } \\
\text { reactions. } \\
\text { Drug-related toxicity: neutropenia, thrombocytopenia, } \\
\text { eosinophilia, thrombophlebitis, chills, fever, rash, } \\
\text { nephrotoxicity, and ototoxicity }[60,82,83]\end{array}$ & $\begin{array}{l}\text { VRE: selection pressure by } \\
\text { indiscriminate use of vancomycin, linked } \\
\text { to at least } 4 \text { genes (Van A-D); } \\
\text { VISA/VRSA: thickened and aggregated } \\
\text { cell walls } \\
\text { Resistance of S. epidermidis: biofilm } \\
\text { [82,83] }\end{array}$ \\
\hline \multicolumn{4}{|l|}{$\beta$-lactams } \\
\hline Piperacillin/Tazobactam & $\begin{array}{l}\text { Wide spectrum of activity against } \\
\text { Gram-positive/Gram-negative aerobic and anaerobic } \\
\text { pathogens, P. aeruginosa. } \\
\text { Moderate to severe infections, including community and } \\
\text { hospital acquired pneumonia, complicated pelvic and } \\
\text { urinary tract infections, complicated skin and soft tissue } \\
\text { infections, intra-abdominal infection, severe sepsis and } \\
\text { septic shock. Piperacillin is largely used for the treatment of } \\
\text { sensitive strains of } P \text {. aeruginosa [10,57-60]. }\end{array}$ & $\begin{array}{l}\text { Anaphylactic/anaphylactoid reactions; Stevens-Johnson } \\
\text { syndrome and toxic epidermal necrolysis, drug reaction } \\
\text { with eosinophilia; antibiotic-induced pseudomembranous } \\
\text { colitis; bleeding, abnormalities of coagulation tests, such as } \\
\text { clotting time, platelet aggregation and prothrombin time; } \\
\text { leukopenia, neutropenia; nephrotoxicity }[53,83] \text {. }\end{array}$ & $\begin{array}{l}\text { Resistance in E. coli: inhibitor-resistant } \\
\text { variants within the TEM and SHV } \beta \\
\text {-lactamase families; overexpression of } \\
\text { inhibitor-sensitive enzymes, such as } \\
\text { BlaTEM-1 }[82,83] \text {. }\end{array}$ \\
\hline Ceftazidime & $\begin{array}{l}\text { Gram-negative germs, such as P. aeruginosa, E. cloacae, E. } \\
\text { coli, H. influenzae, K. pneumoniae. } \\
\text { Febrile neutropenia in children, respiratory tract infections, } \\
\text { especially in children with CF that present chronic } \\
\text { infections by P. aeruginosa [ } 60-63] \text {. }\end{array}$ & $\begin{array}{l}\text { Maculopapular or morbilliform skin eruptions, drug fever, } \\
\text { and a positive Coombs test; anaphylaxis; granulocytopenia; } \\
\text { renal toxicity; disulfiram-like reactions [83]. }\end{array}$ & $\begin{array}{l}\text { Inactivation by bacterial } \beta \text {-lactamases, } \\
\text { alteration of PBPs, and alteration of } \\
\text { bacterial permeability to cephalosporins: } \\
\text { susceptible to hydrolysis by the } \\
\text { inducible, chromosomally encoded } \\
\beta \text {-lactamases and the plasmid } \\
\text { extended-spectrum } \beta \text {-lactamases [83]. }\end{array}$ \\
\hline Cefepime & $\begin{array}{l}\text { Enterobacteriaceae, E. coli, Proteus spp, Klebsiella spp, } S \text {. } \\
\text { pneumoniae, MSSA strains, multidrug-resistant } \\
\text { Gram-negative bacteria, such as AmpC } \beta \\
\text {-lactamase-producing strains and several strains of } \\
\text { ESBL-producing organisms. } \\
\text { Urinary tract and lower respiratory infections in children } \\
{[66,70] \text {. }}\end{array}$ & $\begin{array}{l}\text { Maculopapular or morbilliform skin eruptions, drug fever, } \\
\text { and a positive Coombs test; anaphylaxis; granulocytopenia; } \\
\text { renal toxicity; disulfiram-like reactions [83]. }\end{array}$ & $\begin{array}{l}\text { inactivation by bacterial } \beta \text {-lactamases, } \\
\text { alteration of PBPs, and alteration of } \\
\text { bacterial permeability to cephalosporins; } \\
\text { poor inducer of type I } \beta \text {-lactamases and } \\
\text { less susceptible to hydrolysis [83]. }\end{array}$ \\
\hline Meropenem & $\begin{array}{l}\text { Gram-negative and Gram-positive microorganisms } \\
\text { Enterobacteriaceae, P.aeruginosa, Bacteroides spp, } H \text {. } \\
\text { influenzae, N, gonorrheae, S. aureus, s. epidermidis, } \\
\text { S.saprophiticus, coagulase negative streptococci. In } \\
\text { combination with other antibacterial agents: MSSA, S. } \\
\text { pyogenes, S. agalactiae, S, pneumonia. E. faecium strains are } \\
\text { resistant. } \\
\text { Meningitis, intra-abdominal infections, lower respiratory } \\
\text { infections, bacteremia and sepsis [75]. }\end{array}$ & $\begin{array}{l}\text { Seizures, CNS adverse events, diarrhea, rash, nausea, and } \\
\text { vomiting [83]. }\end{array}$ & $\begin{array}{l}\text { Hydrolyzed by the } \beta \text {-lactamases of S. } \\
\text { maltophilia. Does not bind to the PBPs of } \\
\text { E. faecium. Resistance due to decreased } \\
\text { permeability is uncommon [83]. }\end{array}$ \\
\hline
\end{tabular}

Abbreviations: CNS: Central Nervous System; MRSA: Methicillin Resistant S. aureus; VRE: Vancomycin-resistant Enterococci; VISA/VRSA: Vancomycin Intermediate/Resistant S. aureus; PBP: Penicillin Binding Proteins; CF: Cystic Fibrosis; MSSA: Methicillin Sensitive S. aureus; ESBL: Extended-Spectrum $\beta$-Lactamase. 


\section{Conclusions}

Pediatric patients represent a challenging population, showing variations in pharmacokinetics throughout the different ages. The question whether time-dependent antibiotics should be administered in continuous or intermittent infusion is still open, with few studies led on children and adult data not being fully extendable.

Indeed, prolonged and continuous infusions of antibiotics seem to have a greater probability of target attainment as compared to intermittent infusion regimens, with generally good clinical outcomes and tolerability and safety profile, and therefore should be considered in the pediatric population on a case-to-case basis. This way of administration also has the advantage of being cost-effective on a hospital basis and may be considered to reduce the length of hospitalization in stable children, as continuous infusion treatments can be administered at home with home-based or out clinic-based once-daily changes of infusion device [19]. However, further studies are needed in order to better explore the feasibility, acceptability and impact of this drug-administration strategy, among the pediatric population. It should be taken into consideration that continuous infusion regimens may have some limitations, such as limited molecule stability for some drugs, the need for additional intravenous accesses for hospitalized patients and the association with unavoidable limited mobility of patients.

Our narrative review has some limitations: well-designed included studies were scarce and with different designs, therefore comparison between studies was not possible. Furthermore, we only considered studies in English, leading to the possibility of missing further data published in other languages. In light of results from $\mathrm{pK} / \mathrm{pD}$ studies and considering the reported safety and tolerability of prolonged or continuous antibiotic infusion, our review highlights the need of conducting randomized-controlled trials aimed at exploring the clinical impact, tolerability and patient's acceptability of continuous administration of time-dependent antibiotic administration, compared to intermittent infusion, in the neonatal and paediatric population.

Author Contributions: Conceptualization, P.C. and D.D.; methodology, P.C. and C.M.; validation, E.B. and D.D.; investigation, P.C., C.M. and E.C.; resources and data curation, P.C., C.M. and E.C.; writing-original draft preparation, P.C., C.M. and E.C.; writing-review and editing, P.C., E.B. and D.D.; visualization and supervision, D.D. and C.G.; each author has approved the submitted version and agrees to be personally accountable for the author's own contributions and for ensuring that questions related to the accuracy or integrity of any part of the work, even ones in which the author was not personally involved, are appropriately investigated, resolved, and documented in the literature. All authors have read and agreed to the published version of the manuscript.

Funding: No external funding for this manuscript. The authors have indicated they have no financial relationships relevant to this article to disclose.

Conflicts of Interest: The authors have indicated they have no potential conflicts of interest to disclose.

\section{References}

1. Hsu, A.J.; Tamma, P.D. Treatment of Multidrug-Resistant Gram-Negative Infections in Children. Clin. Infect. Dis. 2014, 58, 1439-1448. [CrossRef]

2. Shiu, J.; Wang, E.; Tejani, A.M.; Wasdell, M. Continuous versus intermittent infusions of antibiotics for the treatment of severe acute infections. Cochrane Database Syst. Rev. 2013, 28, CD008481. [CrossRef]

3. Chen, C.-H.; Chen, Y.-M.; Chang, Y.-J.; Wang, S.-H.; Chang, C.-Y.; Yen, H.-C. Continuous versus intermittent infusions of antibiotics for the treatment of infectious diseases. Medicine 2019, 98, e14632. [CrossRef]

4. Dulhunty, J.M.; Roberts, J.A.; Davis, J.S.; Webb, S.A.R.; Bellomo, R.; Gomersall, C.; Shirwadkar, C.; Eastwood, G.M.; Myburgh, J.; Paterson, D.L.; et al. Continuous infusion of beta-lactam antibiotics in severe sepsis: A multicenter double-blind, randomized controlled trial. Clin. Infect. Dis. 2013, 56, 236-244. [CrossRef]

5. Yu, Z.; Pang, X.; Wu, X.; Shan, C.; Jiang, S. Clinical outcomes of prolonged infusion (extended infusion or continuous infusion) versus intermittent bolus of meropenem in severe infection: A meta-analysis. PLoS ONE 2018, 13, e0201667. [CrossRef] 
6. Roberts, J.A.; Abdul-Aziz, M.H.; Davis, J.S.; Dulhunty, J.M.; Cotta, M.O.; Myburgh, J.; Bellomo, R.; Lipman, J. Continuous versus intermittent $\beta$-lactam infusion in severe sepsis: A meta-analysis of individual patient data from randomized trials. Am. J. Respir. Crit. Care Med. 2016, 194, 681-691. [CrossRef]

7. Abdul-Aziz, M.H.; Sulaiman, H.; Mat-Nor, M.-B.; Rai, V.; Wong, K.K.; Hasan, M.S.; Rahman, A.N.A.; Jamal, J.A.; Wallis, S.C.; Lipman, J.; et al. Beta-Lactam Infusion in Severe Sepsis (BLISS): A prospective, two-centre, open-labelled randomised controlled trial of continuous versus intermittent beta-lactam infusion in critically ill patients with severe sepsis. Intensive Care Med. 2016, 42, 1535-1545. [CrossRef]

8. Vardakas, K.Z.; Voulgaris, G.L.; Maliaros, A.; Samonis, G.; Falagas, M.E. Prolonged versus short-term intravenous infusion of antipseudomonal $\beta$-lactams for patients with sepsis: A systematic review and meta-analysis of randomised trials. Lancet Infect. Dis. 2018, 18, 108-120. [CrossRef]

9. Pea, F.; Viale, P. The antimicrobial therapy puzzle: Could pharmacokinetic-pharmacodynamic relationships be helpful in addressing the issue of appropriate pneumonia treatment in critically ill patients? Clin. Infect. Dis. 2006, 42, 1764-1771. [CrossRef]

10. Bartelink, I.H.; Rademaker, C.M.A.; Schobben, A.F.A.M.; van den Anker, J.N. Guidelines on paediatric dosing on the basis of developmental physiology and pharmacokinetic considerations. Clin. Pharmacokinet. 2006, 45, 1077-1097. [CrossRef]

11. Blot, S.I.; Pea, F.; Lipman, J. The effect of pathophysiology on pharmacokinetics in the critically ill patient-Concepts appraised by the example of antimicrobial agents. Adv. Drug Deliv. Rev. 2014, 77, 3-11. [CrossRef]

12. Pea, F.; Viale, P.; Furlanut, M. Antimicrobial therapy in critically ill patients: A review of pathophysiological conditions responsible for altered disposition and pharmacokinetic variability. Clin. Pharmacokinet. 2005, 44, 1009-1034. [CrossRef]

13. Nicolau, D.P.; Nightingale, C.H.; Banevicius, M.A.; Fu, Q.; Quintiliani, R. Serum bactericidal activity of ceftazidime: Continuous infusion versus intermittent injections. Antimicrob. Agents Chemother. 1996, 40, 61-64. [CrossRef]

14. Rybak, M.J. The pharmacokinetic and pharmacodynamic properties of vancomycin. Clin. Infect. Dis. 2006, 42 (Suppl. S1), S35-S39. [CrossRef]

15. Mouton, J.W.; Vinks, A.A. Continuous infusion of beta-lactams. Curr. Opin. Crit. Care 2007, 13, 598-606. [CrossRef]

16. Lodise, T.P.; Lomaestro, B.M.; Drusano, G.L. Application of antimicrobial pharmacodynamic concepts into clinical practice: Focus on $\beta$-lactam antibiotics-Insights from the Society of Infectious Diseases Pharmacists. Pharmacotherapy 2006, 26, 1320-1332. [CrossRef]

17. De Hoog, M.; Mouton, J.W.; van den Anker, J.N. New dosing strategies for antibacterial agents in the neonate. Semin. Fetal Neonatal Med. 2005, 10, 185-194. [CrossRef]

18. Moriyama, B.; Henning, S.A.; Childs, R.; Holland, S.M.; Anderson, V.L.; Morris, J.C.; Wilson, W.H.; Drusano, G.L.; Walsh, T.J. High-dose continuous infusion beta-lactam antibiotics for the treatment of resistant Pseudomonas aeruginosa infections in immunocompromised patients. Ann. Pharmacother. 2010, 44, 929-935. [CrossRef]

19. Walker, M.C.; Lam, W.M.; Manasco, K.B. Continuous and extended infusions of beta-lactam antibiotics in the pediatric population. Ann. Pharmacother. 2012, 46, 1537-1546. [CrossRef]

20. Butler, M.S.; Hansford, K.A.; Blaskovich, M.A.T.; Halai, R.; Cooper, M.A. Glycopeptide antibiotics: Back to the future. J. Antibiot. 2014, 67, 631-644. [CrossRef]

21. Butterfield, J.M.; Patel, N.; Pai, M.P.; Rosano, T.G.; Drusano, G.L.; Lodise, T.P. Refining vancomycin protein binding estimates: Identification of clinical factors that influence protein binding. Antimicrob. Agents Chemother. 2011, 55, 4277-4282. [CrossRef]

22. Taketomo, C.K.; Hodding, J.H.K.D. Pediatric Dosage Handbook, 14th ed.; Lexi-Comp: Hudson, OH, USA, 2007.

23. Jacqz-Aigrain, E.; Leroux, S.; Zhao, W.; van den Anker, J.N.; Sharland, M. How to use vancomycin optimally in neonates: Remaining questions. Expert Rev. Clin. Pharmacol. 2015, 8, 635-648. [CrossRef]

24. Frymoyer, A.; Hersh, A.L.; Benet, L.Z.; Guglielmo, J. Current recommended dosing of vancomycin for children with invasive methicillin-resistant Staphylococcus aureus infections is inadequate. Pediatr. Infect. Dis. J. 2009, 28, 398-402. [CrossRef]

25. Lilley, L.; Legge, D.; Parkville, V. Paediatric Injectable Guidelines. Aust. Prescr. 2017, 40, 158. [CrossRef] 
26. Gomez, D.S.; Campos, E.V.; de Azevedo, R.P.; da Silva-Jr, J.M.; Ferreira, M.C.; Sanches-Giraud, C.; Vieira Silva, C., Jr.; Santos, S.R.C.J. Individualised vancomycin doses for paediatric burn patients to achieve PK/PD targets. Burns 2013, 39, 445-450. [CrossRef]

27. Le, J.; Bradley, J.S.; Murray, W.; Romanowski, G.L.; Tran, T.T.; Nguyen, N.; Cho, S.; Natale, S.; Bui, I.; Tran, T.M.; et al. Improved vancomycin dosing in children using area under the curve exposure. Pediatr. Infect. Dis. J. 2013, 32, e155-e163. [CrossRef]

28. Zhao, W.; Lopez, E.; Biran, V.; Durrmeyer, X.; Fakhoury, M.; Jacqz-Aigrain, E. Vancomycin continuous infusion in neonates: Dosing optimisation and therapeutic drug monitoring. Arch. Dis. Child. 2013, 98, 449-453. [CrossRef]

29. Genuini, M.; Oualha, M.; Bouazza, N.; Moulin, F.; Treluyer, J.-M.; Lesage, F.; Renolleau, S.; Benaboud, S. Achievement of therapeutic vancomycin exposure with continuous infusion in critically Ill children. Pediatr. Crit. Care Med. 2018, 19, e263-e269. [CrossRef]

30. Germovsek, E.; Osborne, L.; Gunaratnam, F.; Lounis, S.A.; Busquets, F.B.; Standing, J.F.; Sinha, A.K. Development and external evaluation of a population pharmacokinetic model for continuous and intermittent administration of vancomycin in neonates and infants using prospectively collected data. J. Antimicrob. Chemother. 2019, 74, 1003-1011. [CrossRef]

31. Cataldo, M.A.; Tacconelli, E.; Grilli, E.; Pea, F.; Petrosillo, N. Continuous versus intermittent infusion of vancomycin for the treatment of gram-positive infections: Systematic review and meta-analysis. J. Antimicrob. Chemother. 2012, 67, 17-24. [CrossRef]

32. Wysocki, M.; Delatour, F.; Faurisson, F.; Rauss, A.; Pean, Y.; Misset, B.; Thomas, F.; Timsit, J.F.; Similowski, T.; Mentec, H.; et al. Continuous versus intermittent infusion of vancomycin in severe Staphylococcal infections: Prospective multicenter randomized study. Antimicrob. Agents Chemother. 2001, 45, 2460-2467. [CrossRef] [PubMed]

33. Hao, J.-J.; Chen, H.; Zhou, J.-X. Continuous versus intermittent infusion of vancomycin in adult patients: A systematic review and meta-analysis. Int. J. Antimicrob. Agents 2016, 47, 28-35. [CrossRef] [PubMed]

34. Zylbersztajn, B.L.; Chicco, P.; Vega, L.; Centeno, M.; Filippini, S.; Ruvinsky, S. Continuous infusion of vancomycin in pediatric critical care. Arch. Argent Pediatr. 2013, 111, e31-e34. [CrossRef]

35. Gwee, A.; Cranswick, N.; McMullan, B.; Perkins, E.; Bolisetty, S.; Gardiner, K.; Daley, A.; Ward, M.; Chiletti, R.; Donath, S.; et al. Continuous versus intermittent Vancomycin infusions in infants: A randomized controlled trial. Pediatrics 2019, 143, e20182179. [CrossRef]

36. Demirel, B.; Imamoglu, E.; Gursoy, T.; Demirel, U.; Topcuoglu, S.; Karatekin, G.; Ovali, F. Comparison of intermittent versus continuous vancomycin infusion for the treatment of late-onset sepsis in preterm infants. J. Neonatal Perinatal Med. 2015, 8, 149-155. [CrossRef]

37. Hurst, A.L.; Baumgartner, C.; MacBrayne, C.E.; Child, J. Experience with continuous infusion vancomycin dosing in a large pediatric hospital. J. Pediatric Infect. Dis. Soc. 2019, 8, 174-179. [CrossRef]

38. Voumard, R.; Gardiol, C.; André, P.; Arensdorff, L.; Cochet, C.; Boillat-Blanco, N.; Decosterd, L.; Buclin, T.; de Valliere, S. Efficacy and safety of continuous infusions with elastomeric pumps for outpatient parenteral antimicrobial therapy (OPAT): An observational study. J. Antimicrob. Chemother. 2018, 73, 2540-2545. [CrossRef]

39. Verrall, A.J.; Llorin, R.; Tam, V.H.; Lye, D.C.; Sulaiman, Z.; Zhong, L.; Archuleta, S.; Fisher, D.A. Efficacy of continuous infusion of vancomycin for the outpatient treatment of methicillin-resistant Staphylococcus aureus infections. J. Antimicrob. Chemother. 2012, 67, 2970-2973. [CrossRef]

40. Mandell, G.; Dolin, R.; Bennett, J. Principles and Practice of Infectious Diseases, 8th ed.; Elsevier: Amsterdam, The Netherlands, 2015. Available online: https://www.sciencedirect.com/book/9781455748013/mandelldouglas-and-bennetts-principles-and-practice-of-infectious-diseases (accessed on 18 November 2019).

41. Craig, W.A. Pharmacokinetic/Pharmacodynamic parameters: Rationale for antibacterial dosing of mice and men. Clin. Infect. Dis. 1998, 26, 1-10. [CrossRef]

42. Drusano, G.L. Antimicrobial pharmacodynamics: Critical interactions of 'bug and drug'. Nat. Rev. Microbiol. 2004, 2, 289-300. [CrossRef]

43. Lodise, T.P.; Lomaestro, B.; Drusano, G.L. Piperacillin-tazobactam for Pseudomonas aeruginosa infection: Clinical implications of an extended-infusion dosing strategy. Chin. J. Infect. Chemother. 2008, 2004, $357-363$. [CrossRef] [PubMed] 
44. Kalil, A.C.; Metersky, M.L.; Klompas, M.; Muscedere, J.; Sweeney, D.A.; Palmer, L.B.; Napolitano, L.M.; O'Grady, N.P.; Bartlett, J.G.; Carratalà, J.; et al. Management of adults with hospital-acquired and ventilator-associated Pneumonia: 2016 clinical practice guidelines by the Infectious Diseases Society of America and the American Thoracic Society. Clin. Infect. Dis. 2016, 63, e61-e111. [CrossRef] [PubMed]

45. Rhodes, A.; Evans, L.E.; Alhazzani, W.; Levy, M.M.; Antonelli, M.; Ferrer, R.; Kumar, A.; Sevransky, J.E.; Sprung, C.L.; Nunnally, M.E.; et al. Surviving Sepsis Campaign. Crit. Care Med. 2017, 45, 486-552. [CrossRef]

46. Stevens, D.L.; Bisno, A.L.; Chambers, H.F.; Dellinger, E.P.; Goldstein, E.J.C.; Gorbach, S.L.; Hirschmann, J.V.; Kaplan, S.L.; Montoya, J.G.; Wade, J.C.; et al. Practice guidelines for the diagnosis and management of skin and soft tissue infections: 2014 update by the Infectious Diseases Society of America. Clin. Infect. Dis. 2014, 59, e10-e52. [CrossRef]

47. Solomkin, J.S.; Mazuski, J.E.; Bradley, J.S.; Rodvold, K.A.; Goldstein, E.J.C.; Baron, E.J.; O'Neill, P.J.; Chow, A.W.; Dellinger, E.P.; Eachempati, S.R.; et al. Diagnosis and management of complicated intra-abdominal infection in adults and children: Guidelines by the Surgical Infection Society and the Infectious Diseases Society of America. Clin. Infect. Dis. 2010, 50, 133-164. [CrossRef]

48. Bonkat, G.; Pickard, R.; Bartoletti, R.; Bruyère, F.; Geerlings, S.E.; Wagenlehner, F.; Wullt, B. EAU Guidelines on Urological Infections. 2018. Available online: https://uroweb.org/wp-content/uploads/EAU-Guidelineson-Urological-Infections-2018-large-text.pdf (accessed on 14 June 2019).

49. De Cock, P.A.J.G.; van Dijkman, S.C.; de Jaeger, A.; Willems, J.; Carlier, M.; Verstraete, A.G.; Delanghe, J.R.; Robays, H.; Walle, J.V.; Pasqua, O.E.D.; et al. Dose optimization of piperacillin/tazobactam in critically ill children. J. Antimicrob. Chemother. 2017, 72, 2002-2011. [CrossRef]

50. Masterton, R.G.; Kuti, J.L.; Turner, P.J.; Nicolau, D.P. The OPTAMA programme: Utilizing MYSTIC (2002) to predict critical pharmacodynamic target attainment against nosocomial pathogens in Europe. J. Antimicrob. Chemother. 2005, 55, 71-77. [CrossRef]

51. Cies, J.J.; Shankar, V.; Schlichting, C.; Kuti, J.L. Population pharmacokinetics of piperacillin/tazobactam in critically ill young children. Pediatr. Infect. Dis. J. 2014, 33, 168-173. [CrossRef]

52. Nichols, K.; Chung, K.; Knoderer, C.A.; Buenger, L.E.; Healy, D.P.; Dees, J.; Crumby, A.S.; Kays, M.B. Population pharmacokinetics and pharmacodynamics of extended-infusion Piperacillin and Tazobactam in critically Ill children. Antimicrob. Agents Chemother. 2016, 60, 522-531. [CrossRef]

53. Chen, Y.; Lu, J.; Dong, M.; Wu, D.; Zhu, Y.; Li, Q.; Chen, C.; Li, Z. Target attainment analysis and optimal sampling designs for population pharmacokinetic study on piperacillin/tazobactam in neonates and young infants. Eur. J. Clin. Pharmacol. 2016, 72, 1479-1488. [CrossRef]

54. Maarbjerg, S.F.; Thorsted, A.; Kristoffersson, A.; Friberg, L.E.; Nielsen, E.I.; Wang, M.; Brock, B.; Schroder, H. Piperacillin pharmacokinetics and target attainment in children with cancer and fever: Can we optimize our dosing strategy? Pediatr. Blood Cancer 2019, 66, 1-9. [CrossRef] [PubMed]

55. Courter, J.D.; Kuti, J.L.; Girotto, J.E.; Nicolau, D.P. Optimizing bactericidal exposure for $\beta$-lactams using prolonged and continuous infusions in the pediatric population. Pediatr. Blood Cancer 2009, 53, 379-385. [CrossRef] [PubMed]

56. Delvallée, M.; Mazingue, F.; Abouchahla, W.; Delebarre, M.; Wallet, F.; Courcol, R.; Kipnis, E.; Dessein, R. Optimization of continuous infusion of piperacillin-tazobactam in children with fever and neutropenia. Pediatr. Infect. Dis. J. 2013, 32, 962-964. [CrossRef]

57. Thibault, C.; Lavigne, J.; Litalien, C.; Kassir, N.; Théorêt, Y.; Autmizguine, J. Population pharmacokinetics and safety of Piperacillin-Tazobactam extended infusions in infants and children. Antimicrob. Agents Chemother. 2019, 63. [CrossRef]

58. Solórzano-Santos, F.; Quezada-Herrera, A.; Fuentes-Pacheco, Y.; Rodriguez-Coella, G.; Aguirre-Morales, C.E.; Izelo-Flores, D.; Munoz-Hernandez, O.; Miranda-Novales, M.G.; Labra-Zamora, M.G. Piperacillin/Tazobactam in continuous infusion versus intermittent infusion in children with febrile neutropenia. Rev. Investig. Clín. 2019, 71, 10-12. [CrossRef]

59. Knoderer, C.A.; Karmire, L.C.; Andricopulos, K.L.; Nichols, K.R. Extended infusion of Piperacillin/Tazobactam in children. J. Pediatr. Pharmacol. Ther. 2017, 22, 212-217. [CrossRef]

60. American Academy of Pediatrics (AAP). Red Book: 2015 Report of the Committee on Infectious Diseases, 30th ed.; Kimberlin, D.W., Brady, M.T., Jackson, M.A., Long, S.A.E., Eds.; Elk Grove Village IAA of P: Elk Grove Village, IL, USA, 2015. 
61. Tunkel, A.R.; Hartman, B.J.; Kaplan, S.L.; Kaufman, B.A.; Roos, K.L.; Scheld, W.M.; Whitley, R.J. Practice Guidelines for the Management of Bacterial Meningitis. Clin. Infect. Dis. 2004, 39, 1267-1284. [CrossRef]

62. Rains, C.P.; Bryson, H.M.; Peters, D.H. Ceftazidime. An update of its antibacterial activity, pharmacokinetic properties and therapeutic efficacy. Drugs 1995, 49, 577-617. [CrossRef]

63. David, T.J.; Devlin, J. Continuous infusion of ceftazidime in cystic fibrosis. Lancet 1989, 1, $1454-1455$. [CrossRef]

64. Cojutti, P.G.; Maximova, N.; Schillani, G.; Hope, W.; Pea, F. Population pharmacokinetics of continuous-infusion ceftazidime in febrile neutropenic children undergoing HSCT: Implications for target attainment for empirical treatment against Pseudomonas aeruginosa. J. Antimicrob. Chemother. 2019, 74, 1648-1655. [CrossRef]

65. Dalle, J.H.; Gnansounou, M.; Husson, M.-O.; Lambilliotte, A.; Mazingue, F.; Nelken, B. Continuous infusion of ceftazidime in the empiric treatment of febrile neutropenic children with cancer. J. Pediatr. Hematol. Oncol. 2002, 24, 714-716. [CrossRef] [PubMed]

66. Rappaz, I.; Decosterd, L.A.; Bille, J.; Pilet, M.; Belaz, N.; Roulet, M. Continuous infusion of ceftazidime with a portable pump is as effective as thrice-a-day bolus in cystic fibrosis children. Eur. J. Pediatr. 2000, 159, 919-925. [CrossRef] [PubMed]

67. Hubert, D.; Le Roux, E.; Lavrut, T.; Wallaert, B.; Scheid, P.; Manach, D.; Grenet, D.; Sermet-Gaudelus, I.; Ramel, S.; Cracowski, C.; et al. Continuous versus intermittent infusions of ceftazidime for treating exacerbation of cystic fibrosis. Antimicrob. Agents Chemother. 2009, 53, 3650-3656. [CrossRef]

68. Jones, T.E.; Selby, P.R.; Mellor, C.S.; Cheam, D.B. Ceftazidime stability and pyridine toxicity during continuous i.v. infusion. Am. J. Health Syst. Pharm. 2019, 76, 200-205. [CrossRef]

69. Johns Hopkins. Johns Hopkins Antibiotics Guide; Unbound Medicine: Charlottesville, VA, USA, 2019.

70. Blumer, J.L.; Reed, M.D.; Knupp, C. Review of the pharmacokinetics of cefepime in children. Pediatr. Infect. Dis. J. 2001, 20, 337-342. [CrossRef]

71. Shoji, K.; Bradley, J.S.; Reed, M.D.; van den Anker, J.N.; Domonoske, C.; Capparelli, E.V. Population pharmacokinetic assessment and pharmacodynamic implications of pediatric cefepime dosing for susceptible-dose-dependent organisms. Antimicrob. Agents Chemother. 2016, 60, 2150-2156. [CrossRef]

72. Nichols, K.R.; Karmire, L.C.; Cox, E.G.; Kays, M.B.; Knoderer, C.A. Implementing extended-infusion Cefepime as standard of care in a children's hospital: A prospective descriptive study. Ann. Pharmacother. 2015, 49, 419-426. [CrossRef]

73. Condon, R.E.; Walker, A.P.; Hanna, C.B.; Greenberg, R.N.; Broom, A.; Pitkin, D. Penetration of meropenem in plasma and abdominal tissues from patients undergoing intraabdominal surgery. Clin. Infect. Dis. 1997, 24 (Suppl. S2), S181-S183. [CrossRef]

74. Bradley, J.S.; Sauberan, J.B.; Ambrose, P.G.; Bhavnani, S.M.; Rasmussen, M.R.; Capparelli, E.V. Meropenem pharmacokinetics, pharmacodynamics, and Monte Carlo simulation in the neonate. Pediatr. Infect. Dis. J. 2008, 27, 794-799. [CrossRef]

75. Yatsyk, G.V. Use of meropenem in the treatment of severe infections in newborns. Antibiot. Chemoterapy 1998, 43, 32-33.

76. Bradley, J.S.; Nelson, J.D.; Barnett, E.D.; Cantey, J.B.; Kimberlin, D.W.; Palumbo, P.E.; Sauberan, J.; Howard Smart, J.; Steinbach, W.J. Nelson's Pediatric Antimicrobial Therapy, 23rd ed.; American Academy of Pediatrics: Itasca, IL, USA, 2017.

77. Zobell, J.T.; Young, D.C.; Waters, D.C.; Stockmann, C.; Ampofo, K.; Sherwin, C.M.T.; Spigarelli, M.G. Optimization of anti-pseudomonal antibiotics for cystic fibrosis pulmonary exacerbations: I. aztreonam and carbapenems. Pediatr. Pulmonol. 2012, 47, 1147-1158. [CrossRef] [PubMed]

78. Surveillance of Antimicrobial Resistance in Europe 2018. Available online: https://www.ecdc.europa.eu/en/ publications-data/surveillance-antimicrobial-resistance-europe-2018 (accessed on 18 November 2019).

79. Tacconelli, E.; Cataldo, M.A.; Dancer, S.J.; De Angelis, G.; Falcone, M.; Frank, U.; Kahlmeter, G.; Pan, A.; Petrosillo, N.; Rodríguez-Baño, J.; et al. ESCMID guidelines for the management of the infection control measures to reduce transmission of multidrug-resistant Gram-negative bacteria in hospitalized patients. Clin. Microbiol. Infect. 2014, 20, 1-55. [CrossRef] [PubMed]

80. Berthoin, K.; Le Duff, C.S.; Marchand-Brynaert, J.; Carryn, S.; Tulkens, P.M. Stability of meropenem and doripenem solutions for administration by continuous infusion. J. Antimicrob. Chemother. Engl. 2010, 65, 1073-1075. [CrossRef] 
81. Patel, P.R.; Cook, S.E. Stability of meropenem in intravenous solutions. Am. J. Health Syst. Pharm. 1997, 54, 412-421. [CrossRef] [PubMed]

82. Craig, W.A. Basic pharmacodynamics of antibacterials with clinical applications to the use of beta-lactams, glycopeptides, and linezolid. Infect. Dis. Clin. 2003, 17, 479-501. [CrossRef]

83. Drusano, G.L. Prevention of resistance: A goal for dose selection for antimicrobial agents. Clin. Infect. Dis. 2003, 36 (Suppl. S1), S42-S50. [CrossRef]

84. Mattoes, H.M.; Kuti, J.L.; Drusano, G.L.; Nicolau, D.P. Optimizing antimicrobial pharmacodynamics: Dosage strategies for meropenem. Clin. Ther. 2004, 26, 1187-1198. [CrossRef]

85. Van den Anker, J.N.; Pokorna, P.; Kinzig-Schippers, M.; Martinkova, J.; de Groot, R.; Drusano, G.L.; Sorgel, F. Meropenem pharmacokinetics in the newborn. Antimicrob. Agents Chemother. 2009, 53, 3871-3879. [CrossRef]

86. Pettit, R.S.; Neu, N.; Cies, J.J.; Lapin, C.; Muhlebach, M.S.; Novak, K.J.; Nguyen, S.T.; Saiman, L.; Nicolau, D.P.; Kuti, J.L.; et al. Population pharmacokinetics of meropenem administered as a prolonged infusion in children with cystic fibrosis. J. Antimicrob. Chemother. 2016, 71, 189-195. [CrossRef]

87. Cies, J.J.; Moore, W.S.; Enache, A.; Chopra, A. Population pharmacokinetics and pharmacodynamic target attainment of meropenem in critically ill young children. J. Pediatr. Pharmacol. Ther. 2017, 22, 276-285. [CrossRef]

88. Rapp, M.; Urien, S.; Foissac, F.; Béranger, A.; Bouazza, N.; Benaboud, S.; Bille, E.; Zheng, Y.; Gana, I.; Moulin, F.; et al. Population pharmacokinetics of meropenem in critically ill children with different renal functions. Eur. J. Clin. Pharmacol. 2020, 76, 61-71. [CrossRef] [PubMed]

89. Shabaan, A.E.; Nour, I.; Eldegla, H.E.; Nasef, N.; Shouman, B.; Abdel-Hady, H. Conventional versus prolonged infusion of Meropenem in neonates with gram-negative late-onset Sepsis. Pediatr. Infect. Dis. J. 2017, 36, 358-363. [CrossRef] [PubMed]

90. Padari, H.; Metsvaht, T.; Korgvee, L.-T.; Germovsek, E.; Ilmoja, M.-L.; Kipper, K.; Herodes, K.; Standing, J.F.; Oselin, K.; Lutsar, I. Short versus long infusion of Meropenem in Very-Low-Birth-Weight neonates. Antimicrob. Agents Chemother. 2012, 56, 4760-4764. [CrossRef] [PubMed]

(C) 2020 by the authors. Licensee MDPI, Basel, Switzerland. This article is an open access article distributed under the terms and conditions of the Creative Commons Attribution (CC BY) license (http://creativecommons.org/licenses/by/4.0/). 